\title{
Delusional Jealousy (Othello Syndrome) in 67 Patients with Parkinson's Disease
}

\author{
Hiroshi Kataoka* and Kazuma Sugie \\ Department of Neurology, Nara Medical University, Kashihara, Japan
}

Othello syndrome (OS) is a type of paranoid delusional jealousy, characterized by the false absolute certainty of the infidelity of a partner. Because OS has infrequently occurred in patients with Parkinson's disease (PD), the characteristics of OS in PD remain unclear. We reviewed the clinical characteristics of this syndrome in $\mathrm{PD}$. We reviewed 67 patients who had PD with OS. OS was more common in men (45 patients) than in women (22 patients), and it frequently occurred in middle-aged patients. Until the onset of OS, the duration of PD (range, 2-19.8 years) and the duration of treatment with PD medications (range, 2 months to 18.5 years) varied. At the onset of OS, cognition was preserved in most patients. 42 of 47 patients had other psychiatric disorders in addition to OS, and 5 patients had isolated OS. Persecutory or other paranoid delusions developed in 34 patients with OS. OS was associated with PD medication in 25 of 26 patients, especially

OPEN ACCESS

Edited by:

Maria Fiorella Contarino, Leiden University Medical

Center, Netherlands

Reviewed by: Matteo Bologna, Sapienza Università di Roma, Italy Irene Hegeman Richard,

University of Rochester Medical Center, United States

*Correspondence: Hiroshi Kataoka hk55@naramed-u.ac.jp

Specialty section: This article was submitted to Movement Disorders, a section of the journal Frontiers in Neurology

Received: 23 November 2017 Accepted: 21 February 2018 Published: 07 March 2018

Citation:

Kataoka H and Sugie K (2018)

Delusional Jealousy (Othello

Syndrome) in 67 Patients with

Parkinson's Disease.

Front. Neurol. 9:129.

doi: 10.3389/fneur.2018.00129 in patients, used the dopamine agonists. The dose of the PD medication associated with OS was decreased or these drugs were withdrawn to facilitate the treatment of OS. In most patients, OS disappeared or the severity of OS was reduced. OS is infrequent in patients with PD, but is likely to be easily detected because OS is commonly accompanied by persistent paranoid and sexual delusions. When clinicians encounter such patients, the withdrawal or reduction of dopamine agonists should be attempted, and if necessary, additional treatment with clozapine is recommended.

Keywords: Parkinson, delusional jealously, Othello syndrome, psychosis, dopamine agonist, delusion

\section{INTRODUCTION}

Psychosis in Parkinson's disease (PD) can severely interfere with the quality of life and care of patients. Psychosis is the most frequent cause of admission to a nursing home among patients with PD (1). More than $20 \%$ of all patients with PD are affected by psychosis (2). Typically, psychosis occurs in the late stage of PD and psychotic disorders may be present from the early stages (3). The most common symptoms in PD-related psychosis are visual hallucinations. Othello syndrome (OS) is a type of paranoid delusional jealousy, characterized by the false absolute certainty of the infidelity of a partner, leading to preoccupation with a partner's sexual unfaithfulness based on unfounded evidence (4). OS is accompanied by irrational thoughts and emotions associated with unacceptable or extreme behavior. Because OS has infrequently occurred in patients with $\mathrm{PD}$, the characteristics of OS in PD remain unclear. We focused on OS in PD and reviewed the clinical characteristics of this syndrome.

\section{MATERIALS AND METHODS}

PubMed was searched for relevant publications. The following keywords were used: delusional jealousy, OS, psychosis, delusions, jealousy, and Parkinson. The contents of publications in English 
were reviewed and appropriate articles were included. The references from the reviewed articles were examined for any missed articles. We newly found five case reports, four case series (5-11), and three studies (12-14) in addition to our previous case series (15). We added a new case treated in our institution. We reviewed 67 patients who had PD with OS as shown in Tables 1-3.

TABLE 1 | Clinical characteristics of OS in 67 patients with PD (part 1).

\begin{tabular}{|c|c|c|c|c|c|c|c|c|c|}
\hline & Sex & $\begin{array}{c}\text { Age at } \\
\text { PD onset }\end{array}$ & $\begin{array}{l}\text { Age at } \\
\text { OS onset }\end{array}$ & $\begin{array}{c}\text { Disease } \\
\text { duration } \\
\text { (years) }\end{array}$ & $\begin{array}{c}\text { Duration of } \\
\text { PD therapy } \\
\text { (years) }\end{array}$ & $\begin{array}{l}\text { Hoehn-Yahr } \\
\text { stage }\end{array}$ & $\begin{array}{l}\text { UPDRS } \\
\text { part } 3\end{array}$ & MMSE & Depression \\
\hline Patient 1 [Ref. (5)] & M & 45 & 51 & 7 & 5 & 2.5 & 14 & $\begin{array}{l}30, \text { very mild } \\
\text { cognitive decline }^{a}\end{array}$ & NA \\
\hline Patient 2 [Ref. (5)] & M & 48 & 51 & 4 & 3 & 2.5 & 16 & 30, no cognitive decline ${ }^{a}$ & NA \\
\hline Patient 3 [Ref. (5)] & M & 49 & 55 & 7 & 5 & 3 & 18 & $\begin{array}{l}28, \text { very mild } \\
\text { cognitive decline }^{a}\end{array}$ & NA \\
\hline Patient 4 [Ref. (5)] & $\mathrm{M}$ & 54 & 56 & 3 & 1 & 2.5 & 16 & $\begin{array}{l}30, \text { very mild } \\
\text { cognitive decline }^{a}\end{array}$ & NA \\
\hline Patient 5 [Ref. (5)] & M & 45 & 52 & 8 & 6 & 3 & 18 & $\begin{array}{l}27, \text { very mild } \\
\text { cognitive decline }^{a}\end{array}$ & NA \\
\hline Patient 6 [Ref. (5)] & M & 44 & 49 & 6 & 5 & 2.5 & 19 & $\begin{array}{l}28, \text { very mild } \\
\text { cognitive decline }^{a}\end{array}$ & NA \\
\hline Patient 7 [Ref. (6)] & M & 51 & 44 & 7 & 5 & 2.5 & 19 & $\begin{array}{l}29, \text { very mild } \\
\text { cognitive decline }^{a}\end{array}$ & NA \\
\hline Patient 8 [Ref. (7)] & M & 68 & 74 & 6 & 4.5 & $\begin{array}{c}\text { Moderate } \\
\text { parkinsonism }\end{array}$ & NA & NA & - \\
\hline Patient 9 [Ref. (8)] & $\mathrm{F}$ & 47 & 49 & 2 & 2 months & NA & NA & 28 & - \\
\hline Patient 10 [Ref. (9)] & $\mathrm{F}$ & 49 & 53 & 4 & 1 & NA & NA & No cognitive decline & - \\
\hline Patient 11 [Ref. (10)] & $\mathrm{F}$ & 48 & 58 & 10 & 8 & Worsened & NA & Poor recall & + \\
\hline Patient 12 [Ref. (11)] & M & 49 & 58 & 9 & NA & NA & NA & Normal $^{b}$ & NA \\
\hline Patient 13 [Ref. (11)] & M & 39 & 42 & 3 & NA & NA & NA & Mild dementia ${ }^{b}$ & NA \\
\hline Patient 14 [Ref. (11)] & $\mathrm{F}$ & 53 & 64 & 11 & NA & NA & NA & Very mild dementia ${ }^{b}$ & NA \\
\hline Patient 15 [Ref. (11)] & $\mathrm{M}$ & 43 & 49 & 6 & NA & NA & NA & Normal $^{b}$ & NA \\
\hline Patient 16 [Ref. (11)] & $\mathrm{M}$ & 50 & 56 & 6 & NA & NA & NA & Very mild dementia ${ }^{b}$ & NA \\
\hline Patient 17 [Ref. (11)] & $\mathrm{F}$ & 43 & 56 & 13 & NA & NA & NA & Mild dementia ${ }^{b}$ & NA \\
\hline Patient 18 [Ref. (11)] & $\mathrm{M}$ & 49 & 51 & 2 & NA & NA & NA & Normal $^{\mathrm{b}}$ & NA \\
\hline Patient 19 [Ref. (15)] & $\mathrm{F}$ & 42 & 59 & 17 & 9.75 & 3 & 23 & 30 & - \\
\hline Patient 20 [Ref. (15)] & $\mathrm{F}$ & 59 & 79 & 19.8 & 18.5 & 4 & 17 & 17 & - \\
\hline Patient 21 [Ref. (15)] & $\mathrm{M}$ & 58 & 65 & 7.5 & 6.4 & 3 & 13 & 28 & - \\
\hline Patient 22 & $\mathrm{~F}$ & 66 & 73 & 7 & 6 & 3 & 43 & 16 & - \\
\hline $\begin{array}{l}\text { Patient } 23 \text { [Ref. (12)] } \\
\text { Patient } 24 \text { [Ref. (12)] } \\
\text { Patient } 25 \text { [Ref. (12)] } \\
\text { Patient } 26 \text { [Ref. (12)] } \\
\text { Patient } 27 \text { [Ref. (12)] }\end{array}$ & $2 \mathrm{~F}, 3 \mathrm{M}$ & $46.8 \pm 8.87$ & $56.4 \pm 8.76$ & $10.8 \pm 9.41$ & $6.25 \pm 4.72^{a}$ & NA & NA & $\begin{array}{l}\text { None had } \\
\text { cognitive decline }\end{array}$ & NA \\
\hline 15 patients [Ref. (13)] & $6 \mathrm{~F}, 9 \mathrm{M}$ & $51.3 \pm 7.5$ & $61.2 \pm 6.1$ & $9.9 \pm 5.2$ & NA & $2.0 \pm 0.6$ & $18.0 \pm 3.2$ & $28.9 \pm 1.3$ & $\begin{array}{c}10.6 \pm 6.7 \\
\text { (Beck } \\
\text { depression } \\
\text { inventory) }\end{array}$ \\
\hline 5 patients [Ref. (13)] & $5 \mathrm{M}$ & $60.4 \pm 10.6$ & $71.4 \pm 7.0$ & $11.0 \pm 7.2$ & NA & $2.4 \pm 1.1$ & $20.2 \pm 7.1$ & $20.2 \pm 1.7$ & NA \\
\hline 20 patients [Ref. (14)] & $\begin{array}{c}6 \mathrm{~F}, 14 \\
\mathrm{M}\end{array}$ & $53.5 \pm 9.0$ & $63.7 \pm 7.6$ & NA & NA & $2.1 \pm 0.8$ & NA & NA & NA \\
\hline
\end{tabular}

PD, Parkinson's disease; OS, Othello syndrome; UPDRS, unified Parkinson's disease rating scale; MMSE, min-mental state examination; NA,: not available. ${ }^{a}$ Global deterioration scale.

${ }^{b}$ Clinical dementia rating scale (CDR-SB). 
TABLE 2 | Clinical characteristics of OS in 67 patients with Parkinson's disease (part 2).

\begin{tabular}{|c|c|c|c|c|c|c|}
\hline & $\begin{array}{l}\text { Family history } \\
\text { of psychiatric } \\
\text { disorders }\end{array}$ & $\begin{array}{l}\text { Psychiatry } \\
\text { history }\end{array}$ & Hs & $\begin{array}{l}\text { Other associated } \\
\text { psychiatric } \\
\text { disorders }\end{array}$ & $\begin{array}{l}\text { Influence } \\
\text { on daily } \\
\text { activity }\end{array}$ & $\begin{array}{l}\text { MRI-CT } \\
\text { cerebral } \\
\text { atrophy }\end{array}$ \\
\hline Patient 1 [Ref. (5)] & - & NA & - & - & NA & - \\
\hline Patient 2 [Ref. (5)] & - & NA & - & - & NA & - \\
\hline Patient 3 [Ref. (5)] & - & NA & - & - & NA & Mild \\
\hline Patient 4 [Ref. (5)] & + & NA & - & - & NA & - \\
\hline Patient 5 [Ref. (5)] & + & NA & + & Incest & NA & - \\
\hline Patient 6 [Ref. (5)] & - & NA & + & Paraphilic behavior, frotteurism & NA & - \\
\hline Patient 7 [Ref. (6)] & NA & - & - & Persecutory delusions, hypersexuality & + & NA \\
\hline Patient 8 [Ref. (7)] & NA & - & - & Delusions & NA & NA \\
\hline Patient 9 [Ref. (8)] & NA & NA & - & Persecutory paranoid ideation & + & NA \\
\hline Patient 10 [Ref. (9)] & - & - & - & Delusions & + & - \\
\hline Patient 11 [Ref. (10)] & NA & - & + & Delusions & + & NA \\
\hline Patient 12 [Ref. (11)] & NA & - & NA & Hypersexuality & NA & NA \\
\hline Patient 13 [Ref. (11)] & NA & - & NA & Hypersexuality, pathological gambling & NA & - \\
\hline Patient 14 [Ref. (11)] & NA & Anxiety & NA & Pathological shopping & NA & - \\
\hline Patient 15 [Ref. (11)] & NA & Depression & NA & Hypersexuality & NA & - \\
\hline Patient 16 [Ref. (11)] & NA & - & NA & Hypersexuality, pathological gambling & NA & NA \\
\hline Patient 17 [Ref. (11)] & NA & Anxiety & NA & Hypersexuality & NA & - \\
\hline Patient 18 [Ref. (11)] & NA & Anxiety & NA & Hypersexuality, pathological shopping & NA & - \\
\hline Patient 19 [Ref. (15)] & - & - & + & Persecutory delusions & + & - \\
\hline Patient 20 [Ref. (15)] & - & - & + & Persecutory delusions & + & Both occipitals ${ }^{a}$ \\
\hline Patient 21 [Ref. (15)] & - & - & + & Persecutory delusions & + & Both occipitals ${ }^{a}$ \\
\hline Patient 22 & - & - & + & Persecutory delusions & + & $\begin{array}{l}\text { Both occipitals } \\
\text { and frontals }\end{array}$ \\
\hline Patient 23 [Ref. (12)] & - & - & + & - & + & NA \\
\hline Patient 24 [Ref. (12)] & - & - & - & Persecutory delusions & + & NA \\
\hline Patient 25 [Ref. (12)] & - & - & - & Persecutory delusions & + & NA \\
\hline Patient 26 [Ref. (12)] & - & - & + & Persecutory delusions & + & NA \\
\hline Patient 27 [Ref. (12)] & - & - & - & Persecutory delusions & + & NA \\
\hline 15 patients [Ref. (13)] & $\begin{array}{l}7 \text { Patients } \\
\text { positive }\end{array}$ & $\begin{array}{c}\text { Bipolar } \\
\text { disorder (1) }\end{array}$ & $\begin{array}{c}\text { Two } \\
\text { patients }\end{array}$ & $\begin{array}{l}\text { Delusions in all, pathological } \\
\text { gambling (2), hypersexuality (1) }\end{array}$ & NA & NA \\
\hline 5 patients [Ref. (13)] & $\begin{array}{l}1 \text { Patients } \\
\text { positive }\end{array}$ & $\begin{array}{c}\text { Anxiety } \\
\text { disorder (1) }\end{array}$ & $\begin{array}{c}\text { Four } \\
\text { patients }\end{array}$ & $\begin{array}{l}\text { Delusions in all, hypersexuality } \\
\text { (3), panic (1) }\end{array}$ & NA & NA \\
\hline 20 patients [Ref. (14)] & NA & NA & NA & NA & NA & NA \\
\hline
\end{tabular}

Hs, hallucinations; NA, not available.

a Decreased accumulation on single-photon emission computed tomography.

\section{RESULTS}

\section{Clinical Characteristics of 67 Patients}

Othello syndrome was more common in men (45 patients) than in women (22 patients) and frequently occurred in middleaged patients. 3 elderly patients older than 70 years also had OS. 6 patients had a history of psychiatric disorders and 10 patients had a family history of psychiatric disorders. Until the onset of OS, the duration of PD (range, 2-19.8 years) and the duration of treatment with PD medications (range, 2 months to 18.5 years) varied, and OS developed in two patients (patient 9 and 10) after receiving pramipexole for 2 months. At the onset of OS, the severity of PD (median UPDRS motor score, 18) was relatively mild and patients with an early stage of $P D$ (Hoehn-Yahr 2nd or 3rd stage) frequently presented with OS. One patient (patient 20) had late stage PD with a Hoehn-Yahr score higher than 4 . At the onset of OS, cognition was preserved in most patients, but some patients had mild-to-moderate cognitive impairment. Beck Depression Inventory (no depression $\leq 10$ ) was mildly increased in 15 patients (13). In addition to OS, 42 of 47 patients had other psychiatric disorders as follows: hallucinations in 15, depression in 1 (patient 11), or impulse-control disorders (16) in 14 patients. Eleven patients had hypersexuality, pathological gambling was present in four patients, and pathological shopping was evident in two patients. Persecutory or other paranoid delusions developed in 34 patients with OS. Five patients had isolated OS. Most cases of OS adversely affected the daily lives of the patients.

\section{Associated Parkinsonian Medications}

Othello syndrome was associated with PD medications in 25 of 26 patients. In particular, 22 patients used the following dopamine agonists before the onset of OS: pramipexole in 11 patients, ropinirole in 6 patients, pergolide in 3 patients, apomorphine in 2 patients, and rotigotine in 1 patient. Other PD medications associated with OS were levodopa in five patients, amantadine in two patients, selegiline in one patient, and entacapone in one patient. OS was not associated with PD medication in one patient.

\section{Treatments and Outcomes}

In 47 of the 47 patients, the dose of the PD medication associated with OS was decreased, or these drugs were withdrawn 
TABLE 3 | Association of anti-parkinsonian medications with OS in 67 patients with PD.

\begin{tabular}{|c|c|c|c|c|c|}
\hline & $\begin{array}{l}\text { PD medication } \\
\text { associated } \\
\text { with os }\end{array}$ & $\begin{array}{l}\text { Treatment } \\
\text { of OS }\end{array}$ & $\begin{array}{l}\text { Atypical } \\
\text { neuroleptics } \\
\text { used }\end{array}$ & $\begin{array}{c}\text { Follow-up } \\
\text { periods after } \\
\text { treatment of OS }\end{array}$ & Outcome of OS \\
\hline Patient 1 [Ref. (5)] & $\mathrm{RP}$ & $\mathrm{RP}$ reduction & Clozapine & NA & Reduced \\
\hline Patient 2 [Ref. (5)] & PRX & $\mathrm{PRX}$ reduction & Clozapine & NA & Disappeared \\
\hline Patient 3 [Ref. (5)] & Levodopa, pergolide, AMT & Pergolide reduction, withdrawal of AMT & Clozapine & NA & Reduced \\
\hline Patient 4 [Ref. (5)] & $\mathrm{PRX}$ & Withdrawal of PRX & Quetiapine & NA & Reduced \\
\hline Patient 5 [Ref. (5)] & Levodopa & Levodopa reduction & Clozapine & NA & Reduced \\
\hline Patient 6 [Ref. (5)] & Pergolide & Withdrawal of pergolide & Quetiapine & NA & Reduced \\
\hline Patient 7 [Ref. (6)] & Pelgolide & Pelgolide reduction & Quetiapine & NA & Disappeared \\
\hline Patient 8 [Ref. (7)] & AMT & Withdrawal of AMT & - & 4 years & Disappeared \\
\hline Patient 9 [Ref. (8)] & PRX (2 months before OS) & Switch from PRX to levodopa & Quetiapine & 3 months & Disappeared \\
\hline Patient 10 [Ref. (9)] & PRX (2 months before OS) & Withdrawal of PRX & Quetiapine & 3 months & Reduced \\
\hline Patient 11 [Ref. (10)] & NA & Withdrawal of agonist, ECT, rivastigmine ${ }^{a}$ & Quetiapine & NA & Reduced $^{a}$ \\
\hline Patient 12 [Ref. (11)] & PRX & Withdrawal of PRX & - & NA & Disappeared \\
\hline Patient 13 [Ref. (11)] & PRX & Withdrawal of PRX & - & NA & or reduced \\
\hline Patient 14 [Ref. (11)] & PRX & Withdrawal of PRX & - & NA & \\
\hline Patient 15 [Ref. (11)] & $\mathrm{RP}$ & Withdrawal of RP & - & NA & \\
\hline Patient 16 [Ref. (11)] & PRX & Withdrawal of PRX & - & NA & \\
\hline Patient 17 [Ref. (11)] & $\mathrm{PRX}$ & Withdrawal of PRX & - & NA & \\
\hline Patient 18 [Ref. (11)] & $\mathrm{RP}$ & Withdrawal of RP & - & NA & \\
\hline Patient 19 [Ref. (15)] & $\begin{array}{l}\text { Levodopa ( } 100 \text { mg/day) } \\
\text { increased ( } 4,5 \text { months } \\
\text { before OS) }\end{array}$ & $\begin{array}{l}\text { Withdrawal of TRX, AMT } \\
\text { reduction; PER reduction }\end{array}$ & Quetiapine & 6.5 years & Disappeared \\
\hline Patient 20 [Ref. (15)] & $\begin{array}{l}\text { RP ( } 8 \text { months before OS), } \\
\text { selegiline ( } 11 \text { months } \\
\text { before OS) }\end{array}$ & Withdrawal of resuspension & Quetiapine & 5 years & Disappeared \\
\hline Patient 21 [Ref. (15)] & Not detectable & Withdrawal of ropinirole & Quetiapine & 4.5 years & Disappeared \\
\hline Patient 22 & $\begin{array}{l}\text { Rotigotine (1 weeks } \\
\text { before OS) }\end{array}$ & Withdrawal of rotigotine & Quetiapine & 2.5 years & Disappeared \\
\hline Patient 23 [Ref. (12)] & $\begin{array}{l}\text { Levodopa, apomorphine, } \\
\text { PRX }\end{array}$ & Reduction of dopamine agonists & Clozapine, quetiapine & NA & Reduced \\
\hline Patient 24 [Ref. (12)] & $\begin{array}{l}\text { Levodopa, apomorphine, } \\
\text { entacapone }\end{array}$ & Reduction of apomorphine & Quetiapine & NA & Not improved \\
\hline Patient 25 [Ref. (12)] & PRX & $\mathrm{PRX}$ reduction & - & NA & Disappeared \\
\hline Patient 26 [Ref. (12)] & $\mathrm{RP}$ & $\mathrm{RP}$ reduction & Clozapine & NA & Not improved \\
\hline Patient 27 [Ref. (12)] & $\mathrm{RP}$ & Withdrawal of RP & - & NA & Disappeared \\
\hline 15 patients [Ref. (13)] & NA & $\begin{array}{l}\text { Agonist withdrawal (2) } \\
\text { or reduced (13) }\end{array}$ & $\begin{array}{l}\text { Clozapine (7), quetiapine } \\
\text { (4), aripiprazole (1) }\end{array}$ & NA & $\begin{array}{l}\text { Disappeared (1, } \\
\text { aripiprazole), partial } \\
\text { resolusion (14) }\end{array}$ \\
\hline 5 patients [Ref. (13)] & NA & $\begin{array}{l}\text { Agonist withdrawal } \\
\text { or reduced (4) }\end{array}$ & $\begin{array}{l}\text { Clozapine (2), quetiapine } \\
\text { (3) }\end{array}$ & NA & $\begin{array}{l}\text { Disappeared (2), } \\
\text { partial resolusion (1) }\end{array}$ \\
\hline 20 patients [Ref. (14)] & NA & NA & NA & NA & NA \\
\hline
\end{tabular}

$P D$, Parkinson's disease; OS, Othello syndrome; PRX, pramipexole; RP, ropinirole; AMT, amantadine; TRX, trihexyphenidyl; NA, not available.

aPD medication modification or quetiapine failure.

to facilitate the treatment of OS. In one patient, pramipexole was switched to levodopa. 35 of 47 patients received atypical neuroleptics, such as quetiapine (19 patients) or clozapine (15 patients). Electroconvulsive therapy was effective in one patient. In 43 patients, OS disappeared or the severity of OS was reduced. Seven patients remained free of OS.

\section{DISCUSSION}

\section{Clinical Aspects}

Othello syndrome is an infrequent form of psychosis in PD. However, the interval between the time that OS symptoms are first recognized by the patient and OS is diagnosed by a medical professional was reported to be 4 months (12). If the duration of OS is short or OS has occurred several times, it may be missed.
However, many cases of OS are prolonged or associated with exaggerated behavioral changes of the patients, their spouses, or both. In such cases, OS could be easily recognized because the spouses of the patients consulted physicians to confirm the diagnosis. Also, among the many forms of paranoid delusions, OS is known to be most associated with the belief of spousal infidelity (5). The estimated incidence of OS in PD was reported to be $5.2 \%$ among 116 patients with PD (17), 1.1\% among 563 non-demented patients with PD (5), or $2.48 \%$ among 805 patients with PD (14). OS generally occurs in middle-aged patients $(5,14)$ and younger age was reported to be a risk factor for OS (14). Our review also showed that middle-aged patients frequently presented with OS. OS developed not only in patients with the early onset of the parkinsonian symptoms, but also in patients with advanced PD. Most cases of OS occurred in non-demented patients with PD. 
On the basis of the neuropsychiatric assessments, OS is classified into the following subgroups: demented patients, cognitively preserved patients with a relatively early onset of PD, and cognitively preserved patients in whom OS appeared after dopaminergic medication of variable duration (13). Another study mentioned four subtypes of psychosis in PD (18). Psychotic symptoms occur (1) secondary to environmental factors other than PD, such as medical illness, hospitalization, surgery, or nondopaminergic medication, but this was not seen in our review of OS. (2) Isolated OS or dopaminergic-induced OS, and (3) cholinergic disease-related psychosis or psychosis related to cognitive decline can occur. In our review, cognition was preserved in most patients as reported previously (13), and one cross-sectional study showed that the estimated rate of the dementia among PD patients with OS is similar to that of PD patients without OS (14). The two subtypes are seen in patients with OS. (4) Psychosis related to affective disorders or serotonergic psychosis, such as anxiety, depression, or both was evident in some patients with OS in our review. OS usually did not present as an isolated condition, but was often accompanied by hallucinations appearing independently of OS. Delusions with concomitant hallucinations can be found in patients with $\mathrm{PD}$, and hallucinations without retained insight may progress into more complex and severe psychotic symptoms, including delusions (19). Aberrant sexual behaviors or impulse-control behaviors (16) are more common in patients who use dopamine agonists.

\section{Associated Parkinsonian Medications}

All dopaminergic medications carry the risk of eliciting OS as well as psychotic symptoms. A poor correlation between specific dopaminergic drugs and the onset of OS was reported, but the sample was small (5). In our review, dopamine agonists were related to OS in most patients, consistent with the results of previous studies $(5,8,12,14)$. Also, the younger patients with preserved cognition who had OS had received treatment with a dopamine agonist, suggesting that OS is closely related to dopamine agonists. Evidence of a relation between the use of dopamine agonists and age in patients with OS is lacking, but patients who were younger and more frequently received dopamine agonists trended to have OS (14). The key dopamine receptor is most likely the D3 receptor, since the dopamine D3 receptor is involved in reward, craving, emotional, and cognitive processes (20). Pramipexole is a direct D3 agonist, and the use of pramipexole as an agonist is the most likely cause of OS, as reported previously $(5,11)$. Other agonists can also cause OS because ropinirole or pergolide also share D3 affinity. However, a distinct association between the duration or dose of dopamine agonists and the onset of OS remains uncertain. In one patient, levodopa monotherapy was associated with OS (5).

\section{Possible Pathophysiology}

The pathophysiology of OS is unclear. Psychosis is probably caused by an increase in dopamine in the mesolimbic pathway $(6,21)$, which can potentially cause thought disruption. Increased dopaminergic sensitivity in mesolimbic and mesocortical pathways is involved in the generation of psychosis (22). A patient with PD who had hypersexuality showed the increased regional accumulation of dopamine in the right medial temporal regions on single-photon emission computed tomography, and after lowering the dose of pergolide, the increased accumulation disappeared (23). A higher density of Lewy pathology in the parahippocampus and amygdala (24) and $\alpha$-synuclein in limbic regions (25) has also been described in PD. Moreover, D3 agonists induce a decrease in blood flow in the right frontal lobe (11). Dopaminergic excitation of the limbic region with reduced prefrontal stimulation might cause sensory input from multiple associated cortices to be misinterpreted, which can lead to psychosis, including OS (21). Other serotonergic and cholinergic transmitter systems are also involved (18). Confirmation of this hypothesis must await future studies.

\section{Treatments}

Basically, the treatment of OS is similar to that of psychosis. Withdrawal or reduction of anti-parkinsonian medications is initially considered, and the best option is represented by the withdrawal of dopamine agonists or their replacement by equivalent doses of levodopa (13). In our review, OS disappeared in many patients. However, treatment was unsuccessful in some patients with OS, particularly those who had preserved cognitive function, owing to the rapid onset of a dopamine agonist withdrawal syndrome (26). Patients with persistent OS should be additionally given the antipsychotics clozapine or quetiapine if necessary. Other acetylcholinesterase inhibitors as well as atypical antipsychotics, such as risperidone or olanzapine have been tested. Acetylcholinesterase inhibitors can worsen PD symptoms, such as tremor, as compared with atypical antipsychotics. Clinicians should be aware that these treatment options can adversely affect the motor symptoms of PD.

As for the treatment of overall psychosis in PD, many open-label studies have attested to clozapine's efficacy without impairment of motor function (27-29). Clozapine, in very low doses, was effective with dramatic reductions in psychosis, without significant changes in motor function in a randomized, double-blind placebo-controlled study (PSYCLOPS trial) (30). Only clozapine was given A level support for its use to treat psychosis in patients with PD by the Movement Disorders Society review committee on evidence-based medicine, 2011 version (31). In 2007 review by the American Academy of Neurology's task force on the treatment of $\mathrm{PD}$, clozapine and quetiapine were recommended for "consideration" only (32). There is no clinical trial evidence to support the efficacy of quetiapine. A single open-label study demonstrated that olanzapine was effective in patients with PD who had psychosis (33). However, olanzapine was reported to be ineffective for psychosis and worsened Parkinson motor features $(34,35)$. In April 2016, pimavanserin was approved by the Food and Drug Administration as a novel therapeutic option for psychosis in PD. Pimavanserin acts as an inverse agonist at serotonin 5-HT2A receptors and has negligible effects on other receptors, thereby avoiding worsening of motor symptoms (36).

In conclusion, $\mathrm{OS}$ is infrequent in patents with $\mathrm{PD}$, but is likely to be easily detected because OS is commonly accompanied by persistent paranoid and sexual delusions. When clinicians encounter, such patients, the withdrawal or reduction of dopamine agonists 
should be attempted, and if necessary, additional treatment with clozapine is recommended.

\section{AUTHOR CONTRIBUTIONS}

HK was responsible for the overall study design and wrote the manuscript. HK contributed to the acquisition of data and to

\section{REFERENCES}

1. Goetz CG, Stebbins GT. Risk factors for nursing home placement in advanced Parkinson's disease. Neurology (1993) 43:2227-9. doi:10.1212/WNL.43. 11.2222

2. Lee AH, Weintraub D. Psychosis in Parkinson's disease without dementia: common and comorbid with other non-motor symptoms. Mov Disord (2012) 27:858-63. doi:10.1002/mds.25003

3. Morgante L, Colosimo C, Antonini A, Marconi R, Meco G, Pederzoli M, et al. Psychosis associated to Parkinson's disease in the early stages: relevance of cognitive decline and depression. J Neurol Neurosurg Psychiatry (2012) 83:76-82. doi:10.1136/jnnp-2011-300043

4. Kaplan HI, Sadock BJ, Greeb JA. Kaplan and Sadock's Synopsis of Psychiatry. Williams and Wilkins, Seventh Edition. (1994).

5. Cannas A, Solla P, Floris G, Tacconi P, Marrosu F, Marrosu MG. Othello syndrome in Parkinson disease patients without dementia. Neurologist (2009) 15:34-6. doi:10.1097/NRL.0b013e3181883dd4

6. Cannas A, Solla P, Floris G, Tacconi P, Loi D, Marcia E, et al. Hypersexual behaviour, frotteurism and delusional jealousy in a young parkinsonian patient during dopaminergic therapy with pergolide: a rare case of iatrogenic paraphilia. Prog Neuropsychopharmacol Biol Psychiatry (2006) 30:1539-41. doi:10.1016/j.pnpbp.2006.05.012

7. McNamara P, Durso R. Reversible pathologic jealousy (Othello syndrome) associated with amantadine. J Geriatr Psychiatry Neurol (1991) 4:157-9.

8. Stefanis N, Bozi M, Christodoulou C, Douzenis A, Gasparinatos G, Stamboulis E, et al. Isolated delusional syndrome in Parkinson's disease. Parkinsonism Relat Disord (2010) 16:550-2. doi:10.1016/j.parkreldis.2010. 06.010

9. Pírez-Mora G, Guilabert-Vidal M, Quintanilla-López MÁ. Dopamine agonistinduced Othello's syndrome (delusional jealousy). Actas Esp Psiquiatr (2015) 43:32-4.

10. Scicutella A. Rivastigmine treatment of Othello syndrome and postECT delirium in a patient with Parkinson's disease. J Neuropsychiatry Clin Neurosci (2015) 27:e90. doi:10.1176/appi.neuropsych.14010015

11. Graff-Radford J, Ahlskog JE, Bower JH, Josephs KA. Dopamine agonists and Othello's syndrome. Parkinsonism Relat Disord (2010) 16:680-2. doi:10.1016/j. parkreldis.2010.08.007

12. Georgiev D, Danieli A, Ocepek L, Novak D, Zupancic-Kriznar N, Trost M, et al. Othello syndrome in patients with Parkinson's disease. Psychiatr Danub (2010) 22:94-8.

13. Perugi G, Poletti M, Logi C, Berti C, Romano A, Del Dotto P, et al. Diagnosis, assessment and management of delusional jealousy in Parkinson's disease with and without dementia. Neurol Sci (2013) 34:1537-41. doi:10.1007/ s10072-012-1276-6

14. Poletti M, Perugi G, Logi C, Romano A, Del Dotto P, Ceravolo R, et al. Dopamine agonists and delusional jealousy in Parkinson's disease: a cross-sectional prevalence study. Mov Disord (2012) 27:1679-82. doi:10.1002/mds.25129

15. Kataoka H, Kiriyama T, Eura N, Sawa N, Ueno S. Othello syndrome and chronic dopaminergic treatment in patients with Parkinson's disease. Parkinsonism Relat Disord (2014) 20:337-9. doi:10.1016/j.parkreldis.2013.09.001

16. Voon V, Napier TC, Frank MJ, Sgambato-Faure V, Grace AA, RodriguezOroz $\mathrm{M}$, et al. Impulse control disorders and levodopa-induced dyskinesias in Parkinson's disease: an update. Lancet Neurol (2017) 16:238-50. doi:10.1016/S1474-4422(17)30004-2

17. Marsh L, Williams JR, Rocco M, Grill S, Munro C, Dawson TM. Psychiatric comorbidities in patients with Parkinson's disease and psy- analysis and interpretation of the data. HK and KS contributed to drafting and critical revision of part of the submitted materials.

\section{FUNDING}

HK received JSPS KAKENHI grant number (15K9356). chosis. Neurology (2004) 63:293-300. doi:10.1212/01.WNL.0000129843. 15756.A3

18. Factor SA, McDonald WM, Goldstein FC. The role of neurotransmitters in the development of Parkinson's disease-related psychosis. Eur J Neurol (2017) 24:1244-54. doi:10.1111/ene.13376

19. Forsaa EB, Larsen JP, Wentzel-Larsen T, Goetz CG, Stebbins GT, Aarsland D, et al. A 12-year population-based study of psychosis in Parkinson disease. Arch Neurol (2010) 67(8):996-1001. doi:10.1001/archneurol.2010.166

20. Dodd ML, Klos KJ, Bower JH, Geda YE, Josephs KA, Ahlskog JE. Pathological gambling caused by drugs used to treat Parkinson disease. Arch Neurol (2005) 62:1377-81. doi:10.1001/archneur.62.9.noc50009

21. Wolters EC, Berendse HW. Management of psychosis in Parkinson's disease. Curr Opin Neurol (2001) 14:499-504. doi:10.1097/00019052-20010800000011

22. Wolters EC. Dopaminomimetic psychosis in Parkinson's disease patients: diagnosis and treatment. Neurology (1999) 52:S10-3.

23. Kataoka $\mathrm{H}$, Shinkai $\mathrm{T}$, Inoue $\mathrm{M}$, Ueno $\mathrm{S}$. Increased medial temporal blood flow in Parkinson's disease with pathological hypersexuality. Mov Disord (2009) 24:471-3. doi:10.1002/mds.22373

24. Harding AJ, Broe GA, Halliday GM. Visual hallucinations in Lewy body disease relate to Lewy bodies in the temporal lobe. Brain (2002) 125(Pt2):391-403. doi:10.1093/brain/awf033

25. Kalaitzakis ME, Christian LM, Moran LB, Graeber MB, Pearce RK, Gentleman SM. Dementia and visual hallucinations associated with limbic pathology in Parkinson's disease. Parkinsonism Relat Disord (2009) 15: 196-204. doi:10.1016/j.parkreldis.2008.05.007

26. Rabinak CA, Nirenberg MJ. Dopamine agonist withdrawal syndrome in Parkinson disease. Arch Neurol (2010) 67:58-63. doi:10.1001/archneurol. 2009.294

27. Scholz E, Dichgans J. Treatment of drug-induced exogenous psychosis in parkinsonism with clozapine and fluperlapine. Eur Arch Psychiatry Neurol Sci (1985) 235:60. doi:10.1007/BF00380972

28. Factor SA, Brown D, Molho ES, Podskalny GD. Clozapine: a 2-year open trial in Parkinson's disease patients with psychosis. Neurology (1994) 44:544-6. doi:10.1212/WNL.44.3 Part_1.544

29. Trosch RM, Friedman JH, Lannon MC, Pahwa R, Smith D, Seeberger L, et al. Clozapine use in Parkinson's disease: a retrospective analysis of a large multi-centered clinical experience. Mov Disord (1998) 13:377-82. doi:10.1002/ mds. 870130302

30. Factor SA, Friedman JH, Lannon MC, Oakes D, Bourgeois K; Parkinson Study Group. Clozapine for the treatment of drug-induced psychosis in Parkinson's disease: results of the 12 week open label extension in the PSYCLOPS trial. Mov Disord (2001) 16:135-9. doi:10.1002/1531-8257(200101)16:1<135::AIDMDS1006>3.0.CO;2-Q

31. Seppi K, Weintraub D, Coelho M, Perez-Lloret S, Fox SH, Katzenschlager R, et al. The movement disorder society evidence-based medicine review update: treatments for the non-motor symptoms of Parkinson's disease. Mov Disord (2011) 26:S42-80. doi:10.1002/mds.23884

32. Miyasaki JM, Shannon K, Voon V, Ravina B, Kleiner-Fisman G, Anderson $\mathrm{K}$, et al. Practice Parameter: evaluation and treatment of depression, psychosis, and dementia in Parkinson disease (an evidence-based review): report of the Quality Standards Subcommittee of the American Academy of Neurology. Neurology (2006) 66:996-1002. doi:10.1212/01.wnl.0000215428. 46057.3d

33. Wolters EC, Jansen EN, Tuynman-Qua HG, Bergman PL. Olanzapine in the treatment of dopaminomimetic psychosis in patients with Parkinson's disease. Neurology (1996) 47:1085-7. doi:10.1212/WNL.47.4.1085 
34. OndoWG Levy JK, Vuong KD, Hunter C, Jankovic J. Olanzapine treatment for dopaminergic-hallucinations. Mov Disord (2002) 17:1031-5. doi:10.1002/ mds. 10217

35. Breier A, Sutton VK, Feldman PD, Kadam DL, Ferchland I, Wright P, et al. Olanzapine in the treatment of dopamimetic induced psychosis in patient with Parkinson's disease. Biol Psychiatry (2002) 52:438-45. doi:10.1016/ S0006-3223(02)01392-6

36. Hawkins T, Berman BD. Pimavanserin: a novel therapeutic option for Parkinson disease psychosis. Neurol Clin Pract (2017) 7:157-62. doi:10.1212/ CPJ.0000000000000342
Conflict of Interest Statement: The authors declare that the research was conducted in the absence of any commercial or financial relationships that could be construed as a potential conflict of interest.

Copyright $\Subset 2018$ Kataoka and Sugie. This is an open-access article distributed under the terms of the Creative Commons Attribution License (CC BY). The use, distribution or reproduction in other forums is permitted, provided the original author(s) and the copyright owner are credited and that the original publication in this journal is cited, in accordance with accepted academic practice. No use, distribution or reproduction is permitted which does not comply with these terms. 